\title{
Benzoxazinoids - protective secondary metabolites in cereals: The role and application
}

\author{
Sanja Mikić ${ }^{1 *}$. Shakoor Ahmad ${ }^{2}$ \\ ${ }^{1}$ Institute of Field and Vegetable Crops, Maksima Gorkog 30, Novi Sad, Serbia \\ ${ }^{2}$ University of Agriculture, Faculty of Animal Husbandry and Veterinary Sciences, Department of Animal Health, Peshawar, Pakistan
}

\begin{abstract}
Summary: Benzoxazinoids (BXs) are secondary plant metabolites that provide innate defence against a plethora of pests and pathogens. They are identified both in monocots, namely grasses, and in several families of dicots. Among crops, BXs are best characterised in wheat, maize, and rye. These natural pesticides have inhibitory effects on weeds, insects, plant pathogenic fungi, bacteria, and nematodes. Besides, BXs demonstrated the ability to suppress production of mycotoxins, mitigate negative effects of microelement deficiency and toxicity and attract plant beneficial bacteria in the rhizosphere. Here, we summarise benefits and possible applications of these allelochemicals in pest control, which may be of special interest for production systems based on reduction or elimination of pesticides, such as integrated pest management or organic farming. In the light of it, we discuss possible limitations and risks of BX application that are worth considering. Finally, we refer to available germplasm with high BX level that can be exploited as a source of resistance in cereal breeding programmes.

Key words: allelochemicals, benzoxazinoids, cereal breeding, control measures, DIMBOA, pest control, secondary metabolites
\end{abstract}

\section{Many benefits of benzoxazinoids}

Benzoxazinoids (BXs) are secondary metabolites in some grasses and dicot families that have been wellknown for their antifungal, antibacterial, insecticidal, antifeedant and phytotoxic properties. The beneficial role of BXs is also reflected in their ability to inhibit mycotoxins, alleviate detrimental effects of microelement toxicity, increase micronutrient availability and attract beneficial microorganisms in the plant rhizosphere. Due to the economic importance of the agricultural crops, these natural pesticides have been in detailed studied in cereal species, such as maize (Zea mays L.), wheat (Triticum aestivum L.) and rye (Secale cereale L.).

The BXs showed inhibitory activity against a range of weed species. 2,4-dihydroxy-7-methoxy-2H-1,4-benzoxazin-3 (4H)-one (DIMBOA) and 6-methoxybenzoxazolin-2-one (MBOA) from root exudates of allelopathic wheat suppressed root growth of wild oat (Avena fatua L.) (Perez, 1990), white mustard (Sinapis alba L.) (Belz \& Hurle, 2005) and annual ryegrass, Lolium rigidum Gaudin (Huang et al.,

Corresponding author:

sanja.mikic@ifvcns.ns.ac.rs

Acknowledgements:

This study was funded by Ministry of Education, Science and Technological Development of the Republic of Serbia, under the project TR31073.
2003). In contrast to BXs from wheat root exudates, natural BXs from rye mulch did not exhibit any weed suppression (Tabaglio et al., 2008). In maize, however, methyl jasmonate-induced biosynthesis and accumulation of DIMBOA had allelopathic effect on barnyard grass (Echinochloa crusgalli L.), repressing the weed root growth (Wang et al., 2007).

DIMBOA is involved in maize plant resistance to many boring lepidopteran insects, most notably to the first-brood European corn borer (Ostrinia nubilalis Hübner, ECB) (Cardinal et al., 2006). Several mapping studies detected quantitative trait loci (QTLs) for $O$. nubilalis and O. furnacalis Guenée resistance, linking them to natural variation in BXs (Jampatong et al., 2002; Krakowsky et al., 2004; Xia et al., 2010). Moreover, positive correlations between larval mortality of the stalk corn borer Sesamia nonagrioides Lef. and BX concentrations in different maize lines were observed (Niemeyer, 2009). Some maize pests, such as Spodoptera littoralis Boisduval and Spodoptera frugiperda J.E. Smith, developed a mechanism for detoxication DIMBOA via glycosylation, making this constitutive defence compound ineffective. As a response, maize host plants evolved other mechanisms of resistance against these pests, relying upon strong deterrent activity of 2-hydroxy4,7-dimethoxy-1,4-benzoxazin-3-one (HDMBOA) (Glauser et al., 2011), and thus preventing the maize immunity to be overridden. Maize defence response to 
caterpillar feeding is very fast, within a single hour the genes regulating conversion of DIMBOA-glucoside to HDMBOA-glucoside and/or 2,4-dihydroxy-7,8dimethoxy-1,4-benzoxazin-3-one (DIM 2 BOA) glucoside are expressed (Tzin et al., 2017).

The protective role of DIMBOA was also found to be effective against aphids (Ahmad et al., 2011; Meihls et al., 2013). The importance of resistance to aphids is even greater considering that many aphid species are vectors of cereal viruses. For example, the bird cherryoat aphid Rhopalosiphum padi L. is known to be a vector of barley yellow dwarf virus, a disease that causes significant losses in maize, wheat, barley, oat (Avena sativa L.) and other cereals. When added to artificial diets, DIMBOA reduced the survival, reproduction and feeding of aphids (Cambier et al., 2001). DIMBOA inhibits the activities of esterases and glutathione transferase in aphids disabling them to metabolise insecticides with these enzymes, thus, making them more susceptible to chemical treatments (Mukanganyama et al., 2003). Interestingly, the callose formation triggered by DIMBOA was more efficient mechanism in aphid defence than direct toxicity of DIMBOA or HDMBOA (Meihls et al., 2013). Besides, wheat plants treated with jasmonic acid had elevated concentrations of DIMBOA, which inhibited development of aphids Sitobion avenae Fabricius (Yin et al., 2005).

The BXs confer maize resistance to several pathogenic fungi such as Setosphaeria turcica (Luttrell) Leonard \& Suggs (Ahmad et al., 2011; Rostás, 2007), northern corn leaf blight (Helminthosporium turcicum Pass.), Stenocarpella ear rot (Stenocarpella maydis (Berkeley) Sutton) (Niemeyer, 1988a), Fusarium verticillioides (Sacc.) Nirenberg (Glenn et al., 2002), pathogenic bacteria Erwinia spp. (Corcuera et al., 1978) and other plant pathogens (Basse, 2005). Ahmad et al. (2011) found that extracellular DIMBOA could induce callose formation and $B x$ gene expression reducing the percentage of spores and hyphal length of $S$. turcica. In intercropping system of maize and pepper (Capsicum annum L.), the BXs inhibiting the pepper soil-borne pathogen Phytophthora capsici Leonian were isolated from maize root exudates (Yang et al., 2014). Moreover, the treatment of maize root with elicitors from $P$. capsici and pepper root exudates elevated the level of $B \times$ genes expression and BXs concentration in maize roots and shoots and suppressed the maize pathogen Bipolaris maydis (Y. Nisik. \& C. Miyake) Shoemaker (Ding et al., 2015). Like maize pests, certain pathogens also developed resistance to some BXs. Maize smut (Ustilago maydis (DC.) Corda), for example, is resistant to DIMBOA, but susceptible to MBOA, since the fungus could enzymatically degrade the former, but not the latter (Basse, 2005). In wheat, DIMBOA repressed the expression of genes encoding mycotoxin trichothecene synthesis and conferred resistance to Fusarium head blight (Fusarium graminearum Schwabe) (Etzerodt et al., 2015; Søltoft et al., 2008) and take-all (Gaeumannomyces graminis var. tritici J. Walker) (Gordon-Weeks et al., 2010).
The toxicity of DIMBOA, 2,4-dihydroxy-1,4benzoxazin-3-one (DIBOA), MBOA and 2-benzoxazolin $-2(3 \mathrm{H})$-one $(\mathrm{BOA})$ to the second-stage juveniles of nematode Meloidogyne incognita (Kofoid \& White) Chitwood and DIMBOA and DIBOA to juvenile and the adult stages of Xiphinema americanum-group was demonstrated in the study of Zasada et al. (2005). However, only the DIBOA concentrations in soil of 18 $\mathrm{mg} \mathrm{g}^{-1}$ dry soil were sufficient to suppress $M$. incognita due to microbial degradation and soil binding of DIBOA (Meyer et al., 2009). This was a reason why introducing DIBOA into the soil via rye cover crop incorporation as a method to control plant-parasitic nematodes did not achieve satisfactory effects (Meyer et al., 2009).

Another role of BXs is that they act as strong chelating agents or, more specifically, phytosiderophores, plant chelating compounds that have high affinity to binding micronutrients, such as iron, zinc, copper and manganese (Dakora \& Phillips, 2002). Benzoxazinoids bind to $\mathrm{Fe}^{3+}$ to form $\mathrm{Fe}^{3+}$ - phytosiderophores, increasing this micronutrient availability to plants and thus mitigating iron deficiency (Bais et al., 2006). The application of DIMBOA -iron and DIBOA-iron chelates to iron-deficient maize and oat seedlings withdrew chlorotic symptoms (Petho, 1993). Besides, the ability of DIMBOA from maize root exudates to bind aluminium in soil by chelation protected maize from aluminium toxicity (Poschenrieder et al., 2005).

Moreover, DIMBOA in maize root exudates proved to play an important role in attracting the plant beneficial bacteria Pseudomonas putida in the crop rhizosphere and balancing the ratio of naturally competing microorganisms in soil to the plant's benefit, especially in its young vulnerable stages (Neal et al., 2012). In addition, DIMBOA affects growth promotion by stimulating auxin-induced elongation of maize coleoptiles (Park et al., 2001). As an illustration of a complex plant-microbe interactions in relation to allelopathic compounds, it was found that the soil fungus Actinomucor elegans (Eidam) C.R. Benj. \& Hesselt could colonize the roots of the weed Abutilon theophrasti Medik. in the presence of tryptophan, protecting it against BOA and its toxic derivates (Kia et al., 2014).

The BXs were found to be involved in plant priming, a defence mechanism initiated by an external stimulus that triggers physiological processes in the plant enabling it to more swiftly and efficiently enhance resistance after exposure to abiotic or biotic stress (Frost, 2008). Inoculation of maize roots with the arbuscular mycorrhizal fungus Glomus mosseae (T.H. Nicolson \& Gerd.) Gerd. \& Trappe primed elevated defence response to sheath blight Rhiroctonia solani J.G. Kühn by initiating higher level of DIMBOA accumulation in roots and leaves (Song et al., 2011). Furthermore, root attacks of the western corn rootworm (Diabrotica virgifera virgifera LeConte) induced abscisic acid (ABA) priming for increased concentration of DIMBOA in aboveground parts and enhanced resistance to lepidoptera $S$. littoralis and pathogenic 
fungus S. turcica (Erb et al., 2009). Moreover, leaf infiltration with defence elicitor chitosan enhanced the accumulation of DIMBOA and HDMBOA (Ahmad et al., 2011). The research of Neal and Ton (2013) revealed that priming jasmonic acid-dependant genes, involved in maize defence by root colonization with $P$. putida, was possible only in plants that produced BXs. The plant hormone jasmonic acid was proved to stimulate biosynthesis of DIMBOA (Zheng et al., 2008), which, besides its allelopathic properties, also acted as a signal to activate other defence mechanisms (Meihls et al., 2013). Santiago et al. (2017) found that after maize leaves disruption by $S$. nonagrioides and exposure to methyl-jasmonate, maize plants triggered reactions that converted all DIMBOA-glucoside, which aglycone form can be detoxified by insects, to HDMBOA-glucoside, which aglycone form had strong deterrent activity and cannot be detoxified.

Finally, BXs demonstrated the ability to suppress production of mycotoxins. Strong inhibition of trichothecene mycotoxin accumulation in wheat grain produced by Fusarium head blight wheat pathogen was attributed to DIMBOA, which suppressed synthesis of a transcription factor that regulates trichothecene biosynthesis (Etzerodt et al., 2015). DIMBOA inhibited mycotoxin 15-acetyldeoxynivalenol produced by $F$. graminearum in wheat (Etzerodt et al., 2015), while 4acetyl-benzoxazolin-2-one (4-ABOA) suppressed 3acetyldeoxynivalenol of Fusarium culmorum (W.G. Sm.) Sacc. in maize grain (Miller et al., 1996). Interestingly, Bacillus mojavensis Roberts, Nakamura \& Cohan, a bacterium used for biological control of F. verticilloides, could interact with the wheat pathogen and divert usual metabolism of BOA to 2-aminophenoxazin-3-one (APO), a benzoxazinoid highly toxic to $F$. verticilloides, but not to the bacterium (Bacon et al., 2007).

\section{Benzoxazinoids in crop protection}

Enabling a broad array of resistance mechanisms against a range of pest organisms, BXs have a great potential for crop pest control, especially in resourceconserving agricultural systems. A methodical and thoughtful use of BXs as natural allochemicals could avoid the overuse of less safe pesticides, thus reducing the input costs, preventing accumulation of pesticide residues in food and ecosystems, and reducing overall health and environmental risks. Further health benefits can be reflected in BXs ability to suppress mycotoxins and decrease microelement toxicity. Moreover, as BXs mediate nutrient acquisition and attract plant beneficial bacteria in rhizosphere, their use would facilitate rational application of fertilisers that would minimise nitrate leaching or nitrification losses, micro- or macronutrient deficiency and sustain biological productivity of soils. These benefits are relevant not only for organic agriculture that eschews synthetic pesticides and fertilisers, but also for regenerative agriculture that applies principles of integrated pest management and even for conventional and intensive farming systems.

Some of the practical control measures that could take advantage of BXs properties may include intercropping BX-releasing cereals with other crops, priming cereal resistance by different biological and chemical agents, developing synthetic BX biopesticides and developing new high BXs resistant cultivars. Establishing an intercropping system beneficial for both crop species requires the right choice of species, cultivars and row spacing, as well as the complementary of spatial root distribution and nutrient and water uptake. Such intercroppings would maximise the use of available resources and foster positive interactions with symbiotic mycorrhizal fungi and plant growthpromoting bacteria attracted by BXs from cereal root exudates. At the same time, it should minimise competition among intercrops and ensure protection against the prevalent pests, pathogens and weeds. Furthermore, intercropping may serve as a suitable environment for priming cereal resistance, such was the case with priming maize resistance against southern corn leaf blight (Bipolaris maydis Y. Nisik \& C. Miyake), activated by elicitors from pepper pathogen Phythophthora capsici Leonian or pepper root exudates in maize-pepper intercropping system (Ding et al., 2015). Still, priming could be done by a direct treatment with some natural or synthetic compounds or Pseudomonas-based biopesticides either as a seed treatment, soil drench or foliar spray (Kupferschmied et al., 2013). In addition, natural occuring BXs with pesticidal effects can be isolated and modified to synthetic biochemical pesticides with more bioactive, stable and selective properties that can also quickly breakdown into residuals harmless for the environment. Some cosiderable results in research of synthetic derivatives of BXs as herbicide models have been achieved (Macías et al., 2010). Ultimately, there is a promising prospect for cereal breeders to explore vast genetic resources for natural variation in BXs in order to develop new resistant varieties with high level and durable effects of BXs, while maintaining high yields and quality.

There are several issues related to BXs that are worth considering before opting for a certain control measure. Those are instability of BXs and their decrease with plant ageing, possible negative effects on nontarget organisms, detoxification of BXs by some pathogens and pests, herbicides degradation and putative human health implications. The most effective and most prevalent allelopathic BXs in cereals, DIMBOA and DIBOA, are unstable compounds and spontaneously decompose to MBOA and BOA (Meyer et al., 2009). Moreover, the constitutive concentration of these allelochemicals decreases with time, as plants grow and develop (Cambier et al., 2000), providing inefficient protection in later stages. One such example is the susceptibility of maize to the second generation to 
ECB, which causes more severe damages to the crop comparing to the first generation. Surprisingly, however, a recent finding elucidated the mechanism for prolonged biosynthesis of DIMBOA in later developmental stages of the maize inbred line Mo17 (Zheng et al., 2015). A cis-element, called DICE, located upstream of $B \times 1$ gene, was found to be required for high DIMBOA content and independent of $B \times 1$ transcription. This finding indicates promising prospect of controlling the BXs expression and using inbred lines with high DIMBOA in later stages of breeding for increased plant resistance.

\section{Potential risks of benzoxazinoids}

A wide range of allopathic activities of BXs against numerous crop pathogens, pests, weeds and other organisms that are evolutionary and genetically distant, may raise some concerns regarding the detrimental effects of BXs on beneficial and non-target organisms. Insufficient research has been conducted to support or reject these concerns. Fuentes-Contreras and Niemeyer (1998) found that DIMBOA suppressed the growth of wheat aphids $S$. avenae, but also prolonged the period between the egg and larval stages of the beneficial cereal parasitoid Aphidius rhopalosiphii De Stefani Perez. However, it had no significant impact of parasitoid overall survival, pupal developmental time or body mass. Additionally, no negative effects of DIMBOA and its derivatives were observed on tested collembola and carabid beetle species in soil comparing to the reference and control treatments (Idinger et al., 2006). The lack of data on risk of BXs to non-target organisms and natural enemies points out the need for more research on their potential negative effects.

The ability of cereal pathogens to metabolise toxic DIMBOA, DIBOA, MBOA and BOA was determined in several Fusarium species (Saunders \& Kohn, 2008). The detoxification of $\mathrm{BXs}$ by $F$. verticilioides was attributed to two fungal genes $F d b 1$ and Fdb2 (Glenn et al., 2002). Although the strains with mutant nonfunctional alleles for both loci $(f d b 1 / f d b 2)$ were unable to metabolise BXs, the BXs were not effective enough in providing plant resistance against $F$. verticillioides, suggesting that the pathogen employs other virulence mechanisms (Glenn et al., 2002). It was also demonstrated that wheat pathogenic fungi G. graminis var. graminis and $G$. graminis var. tritici were able to detoxify MBOA and $\mathrm{BOA}$, the former fungus being more efficient and causing more severe symptoms than the latter (Friebe et al., 1998). Since oat cannot produce DIMBOA and DIBOA and its pathogen G. graminis var. avenae is not able to detoxify either them or their products, MBOA and BOA, it was hypothesised that the ability of a pathogen to metabolise plant antimicrobials determines its host range (Niemeyer, 1988a). Enzymatic detoxification of BXs was observed in several insect species: lepidoptera $S$. frugiperda and $S$. littoralis (Glauser et al., 2011), rice armyworm (Mythimna separata Walker) (Sasai et al., 2009) and aphid S. avenae (Leszczynski et al., 1992). Detoxification was based on glucosylation (Glauser et al., 2011), although little is known about genes and enzymes involved in the process (Maag et al., 2014). Some specialist herbivores, such as larvae of the western corn rootworm, showed not only tolerance to high BXs level (Alouw et al., 2015; Davis et al., 2000), but recognised DIMBOA from root exudates as feeding stimulus (Robert et al., 2012). Similarly, DIMBOA stimulated feeding of the $S$. frugiperda in vitro bioassays (Rostás, 2007). In contrast to DIMBOA, HDMBOA could not be detoxified via larvae of Spodoptera spp. (Glauser et al., 2011; Maag et al., 2014). Moreover, an intermediate product of HDMBOA degradation inhibited the virulence gene expression of soil pathogen Agrobacterium tumefaciens (Smith and Townsend) Conn (Maresh et al., 2006). Undoubtedly, HDMBOA certainly deserves more consideration on how to employ its good properties and circumvent its high instability, either as a model for synthetic biochemicals or by other means.

Several studies showed the potential of BXs to hydrolyse herbicides via root exudates. The hydroxamic acids reduced toxicity of thiazine herbicides by hydroxylation (Marcacci et al., 2005; Wenger et al., 2005). Besides, Nicol et al. (1993) found that DIMBOA in maize seedlings reduced median lethal dose of deltamethrin and decreased the insecticide efficiency used to control aphid $S$. avenae. Therefore, the role of BXs in the herbicide degradation can be dual, disadvantageous, as they reduce herbicide efficiency in weeds control, and favourable, in facilitating faster degradation of herbicide residues and eliminating toxicity for the following crop and harmful effects to the environment.

The findings of the studies on the impact of BXs on human health are inconclusive and ambiguous. On one hand, research of Buchmann et al. (2007) suggested that DIMBOA and DIBOA could cause aneuploidy in human-derived liver cells. In the light of their finding, Prinz et al. (2010) raised concerns over the use of wheat sprouts and sprout-derived products in human diet as they detected the highest concentration of DIMBOA (0.04 to $0.47 \%)$ in wheat sprouts three days after germination. Curiously enough, quite contrary findings reporting positive effects of BXs on human health were summarised in the review of Adhikari et al. (2015). BXs and their derivatives were associated with reduced cancer risk (Che et al., 2011; Kato et al., 2006; Wu et al., 2012; Zheng et al., 2010), anti-allergic properties (Poupaert et al., 2005), appetite suppression and weight reduction effects (Rosenfeld \& Forsberg, 2009). Recently, a number of studies identified and quantified BXs in commercially available cereal food products and flours, mostly of rye and wheat (Dihm et al., 2017; Hanhineva et al., 2011; Pedersen et al., 2011; Pihlava et al., 2018; Steffansen et al., 2017), all of them referring to 
BXs as bioactive and human health-promoting compounds. Jensen et al. (2017) studied absorption and metabolism of BXs in humans after the consumption of high- and low-benzoxazinoid diets. They determined peaks in BXs concentration three and 36 hours after consumption in blood and urine, respectively, with a rapid washout from plasma and the extended excretion through urine. Certainly, further research endeavours are needed for more reliable assessments of the potential health risks or benefits of these compounds.

\section{Benzoxazinoids in cereal breeding}

Breeding for new cultivars with high BXs content that would provide the crop prolonged protection against a range of pest organisms is a rather appealing, but at the same time a very challenging task. Despite the considerable knowledge and ever-emerging discoveries on genetic background of BXs biosynthesis, little is known about environmental factors controlling BXs production and genotype by environment interaction, the information that are crucial for breeders. Moreover, research on heritability of BXs production is very scarce. To the best of our knowledge, we found a sole estimate of the narrow sense heritability of DIBOA production in rye that was low $\left(h^{2}=0.18\right)$ on a per plot basis and moderately high $\left(h^{2}=0.57\right)$ on an entry mean basis; the values similar to estimates for maize yield (Brooks et al., 2012). Assuming sufficient heritability and genetic variation of the trait to exploit the BXs potential, one could follow a general breeding scheme that would include three common stages: prebreeding, breeding and yield field trials (Figure 1).

In the first prebreeding stage, genotypes with high BXs concentration should be looked for among breeding material, genebank collections of landraces, old and modern cultivars and ancestral wild relatives. These genetic resources are of great importance as they can be a valuable source in breeding as donors of favourable $B x$ alleles either to elite lines or prebreeding populations. Considering a huge number of genetic resources in available collections, screening all of them for high BXs content would be hardly feasible. Analytic quantification of BXs is expensive, time and labour consuming, and therefore not applicable for a large number of samples. Thus, a previous knowledge about the genotype resistance, $B x$ alleles they contain or even other allochemicals (such as flavonoids, phenolics or salicylic acid) that might jointly provide durable resistance, would be of great help. Functional markers associated with BXs production could be used for efficient and reliable identification and selection of germplasm that harbour favourable alleles and allelic combinations for BX content. Moreover, pedigree information could assist breeders in narrowing down the number of genotypes to a level manageable for application of functional markers. To this end, we summarised the research findings in maize and wheat genetic resources that were characterised for BXs content and resistance.

Maize inbred lines varied in BX content depending on their geographical distribution. The inbred lines of tropical origin showed higher content of HDMBOA comparing to DIMBOA, while in modern temperate lines the ratio between these BXs was opposite (Meihls et al, 2013). Three inbred lines, namely Mo17, B97 and M37W, were identified for aphid resistance and high DIMBOA concentration of $1.5 \mathrm{mM}$ or more in later developmental stages (Zheng et al., 2015). The study of Betsiashvili et al. (2015) confirmed that the Mo17 allele caused increased DIMBOA accumulation. Additionally, B97 inbred line was previously assessed as resistant to ECB (Abel et al., 2000). Inbred lines H99 (Cardinal et al., 2006), B49 and CI31A (Klenke et al., 1987) were found to be resistant to the first generation of ECB and the last two inbred lines also had high levels of DIMBOA. Teosinte ( $Z$. mays ssp. parviglumis Iltis \& Doebley), the maize wild ancestor, showed to be more resistant against herbivory than maize (Lange et al., 2014; Takahashi et al., 2012). Moreover, different expression of defence-related genes was observed between teosintes and maize upon infestation with $S$. frugiperda (Szczepaniec et al., 2013). Although there were no significant differences in BXs accumulation between wild teosintes and cultivated maize, teosintes and old Mexican maize landraces tend to have higher HDMBOA to DIMBOA ratio and their levels of BXs

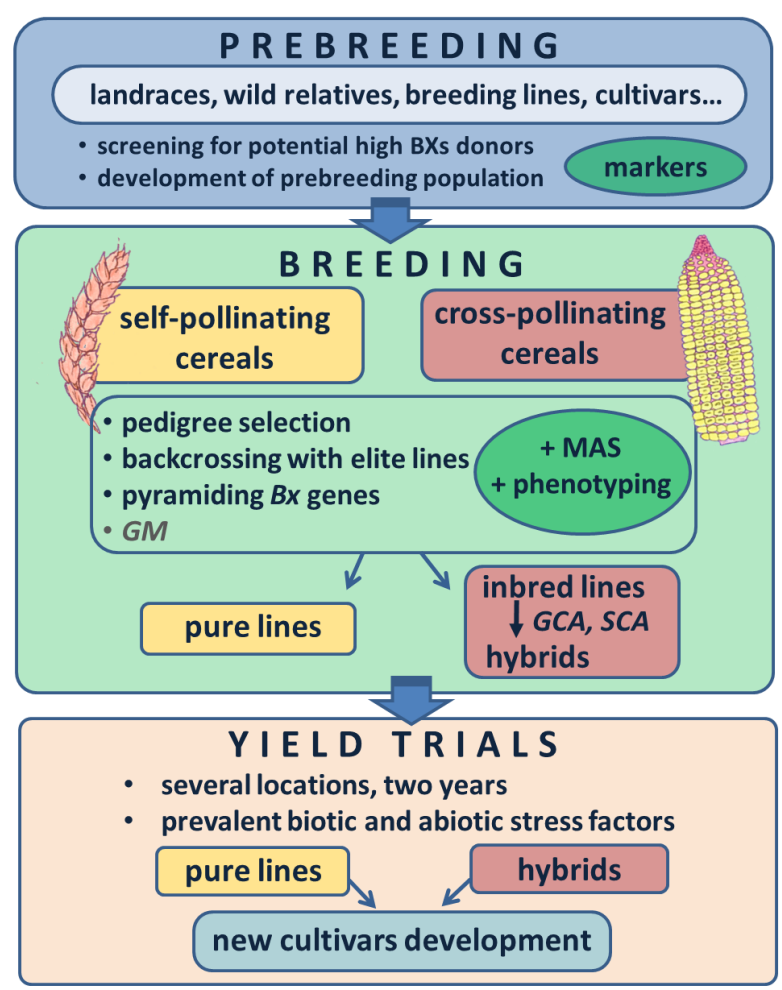

Figure 1. A cereal breeding scheme for new cultivars with enhanced BXs content 
decline more slowly in comparison to modern maize varieties (Maag et al., 2015).

Wheat cultivars can also differ in the BXs content. Among 42 cultivars from 13 countries worldwide screened for DIMBOA content in 4-5-day-old wheat seedlings, Nicol et al. (1992) found one cultivar from Chile (Quilafen), one from the USA (Malcolm) and four from Pakistan (Faisalabad, Belikh, Rawal and Wadanak) that contained $\geq 5 \mathrm{mmol} \mathrm{kg}^{-1}$ of fresh weight. In the study of Wu et al. (2001), seven out of 58 accessions from the Australian Winter Cereals Collection had DIMBOA content $\geq 700 \mathrm{mg} / \mathrm{kg}$ dry matter in both roots and shoots, namely, Sudan 8 (Sudan), AUS18364 (South Africa), Egret (Australia), Batten (New Zealand), Altar 84 (Mexico), Tasman (Australia) and Khapli (India). The BXs were also reported in the wheat wild relatives T. monococcum L., T. boeoticum Boiss., T. urartu Tumanian ex Gandilyan, Aegilops speltoides Tausch, Ae. squarrosa L. (Nomura et al., 2003, 2007; Niemeyer, 1988b) and wild barley species Hordeum roshevitrii Bowden, $H$. flexuosum Nees, H. brachyantherum Nevski, and H. Lechleri (Steud.) Schenck (Grün et al., 2005). Gordon-Weeks et al. (2010) reported higher levels DIMBOA in roots in Ae. speltoides and a durum wheat cultivar than in hexaploid wheat and T. monococcum. High levels of DIMBOA in Ae. speltoides and its negative effect on cherry-oat aphids R. padi was determined by Elek et al. (2013). These findings certainly draw attention to the value of wild crop relatives as a source of BXs for enhancing resistance of modern cultivars.

Cereal breeding approaches differ for autogamous (e.g. wheat or barley) and allogamous species (e.g. rye or maize). However, there are some common steps in breeding self-pollinating and cross-pollinating cereals, such as intermating chosen parents, developing homozygous pure lines and inbred lines from the progenies of the crossed parents through generations of inbreeding and selecting the outstanding progenies during inbreeding. Breeding for improved cultivars with high BXs content and resistance to biotic stress could be achieved by 1) the pedigree method, 2) backcrossing a genotype with high BXs content with an elite line as a recurrent parent or 3) pyramiding favourable $B x$ alleles from multiple parents in a single genotype. These different methods of transferring favourable $B x$ alleles and selecting desired genotypes among progenies can be greatly facilitated by marker assisted selection (MAS). The selected plants should also be screened for disease and/or pest resistance in stress conditions. Regardless of the different attitudes towards GM crops, and with no intention to discuss them here, we ought to mention that in countries where GM regulations advocate this technology, specific gene resistance transfer, overexpression of genes or transcription factors for prolonged BXs synthesis or gene editing might be used for developing new resistant cultivars. In breeding selfpollinating crops, created pure lines can be proceeded to yield testing trials, while breeding cross-pollinating species, such as maize, requires one additional step testing inbred lines for general and special combining abilities followed by the hybrid development. Ultimately, developed pure lines and hybrids should be tested for yield performance and resistance for prevalent diseases and pests in several locations and during at least two years, after which the best performing ones are chosen for the variety registration.

The benefits and opportunities that could arise from the use of BXs in cultivar improvement or cereal pest management would certainly propel further research on the topic to shed more light on the unresolved questions and propose solutions that would overcome existing and foreseen hindrances and thus avail routine implementation of $\mathrm{BXs}$ in cereal production.

\section{Conclusions}

As natural allelochemicals with a broad scope of biological activities, benzoxazinoids have a great potential to be used either directly, extracted and synthetized as new bioactive phytochemicals, or indirectly, in germplasm with an elevated level of BXs concentration efficient for biological control. Considering the economic and environmental benefits, there should be of a great interest in developing strategies for wide and routine use of BXs in crop production. The strategies to overcome limitations that could hamper application of these natural pesticides, as well as to supervise the undesirable effects of their use, should be supported by comprehensive research on genetic and environmental factors controlling BXs production, the interaction of crops and target pest organisms and their complex interrelation to non-target organisms and conditions of the crop-specific agroecosystems.

\section{References}

Abel, C. A., Berhow, M. A., Wilson, R. L., Binder, B. F., \& Hibbard, B. E. (2000). Evaluation of conventional resistance to European corn borer (Lepidoptera: Crambidae) and western corn rootworm (Coleoptera: Chrysomelidae) in experimental maize lines developed from a backcross breeding program. Journal of Economic Entomology, 93(6), 1814-1821.

Adhikari, K. B., Tanwir, F., Gregersen, P. L., Steffensen, S. K., Jensen, B. M., Poulsen, L. K., Nielsen, C.H., Høyer, S., Borre, M., \& Fomsgaard, I. S. (2015). Benzoxazinoids: Cereal phytochemicals with putative therapeutic and health-protecting properties. Molecular Nutrition \& Food Research, 59(7), 1324-1338.

Ahmad, S., Veyrat, N., Gordon-Weeks, R., Zhang, Y., Martin, J., Smart, L., Glauser, G., Merb, M., Flors, V., Frey, M. \& Ton, J. (2011). Benzoxazinoid Metabolites Regulate Innate Immunity against Aphids and Fungi in Maize. Plant Physiology, 157, 317-327.

Alouw, J. C., \& Miller, N. J. (2015). Effects of benzoxazinoids on specialist and generalist Diabrotica species. Journal of Applied Entomology, 139(6), 424-431.

Bacon, C. W., Hinton, D. M., Glenn, A. E., Macías, F. A., \& Marin, D. (2007). Interactions of Bacillus mojavensis and Fusarium verticillioides with a benzoxazolinone (BOA) and its transformation product, APO. Journal of Chemical Ecology, 33(10), 1885-1897. 
Bais, H. P., Weir, T. L., Perry, L. G., Gilroy, S., \& Vivanco, J. M. (2006). The role of root exudates in rhizosphere interactions with plants and other organisms. Annual Review of Plant Biology, 57, 233-266.

Basse, C. W. (2005). Dissecting defense-related and developmental transcriptional responses of maize during Ustilago maydis infection and subsequent tumor formation. Plant Physiology 138(3), 1774-1784.

Belz, R. G., \& Hurle, K. (2005). Differential exudation of two benzoxazinoids - One of the determining factors for seedling allelopathy of Triticeae species. Journal of Agricultural and Food Chemistry, 53, 250-261.

Betsiashvili, M., Ahern, K. R., \& Jander, G. (2015). Additive effects of two quantitative trait loci that confer Rhopalosiphum maidis (corn leaf aphid) resistance in maize inbred line Mo17. Journal of Experimental Botany, 66(2), 571-578.

Brooks, A. M., Danehower, D. A., Murphy, J. P., Reberg-Horton, S. C., \& Burton, J. D. (2012). Estimation of heritability of benzoxazinoid production in rye (Secale cereale) using gas chromatographic analysis. Plant Breeding, 131(1), 104-109.

Buchmann, C. A., Nersesyan, A., Kopp, B., Schauberger, D., Darroudi, F., Grummt, T., Krupitza, G., Kundi, M., SchulteHermann, R., \& Knasmueller, S. (2007). Dihydroxy-7-methoxy-1, 4-benzoxazin-3-one (DIMBOA) and 2, 4-dihydroxy-1, 4benzoxazin-3-one (DIBOA), two naturally occurring benzoxazinones contained in sprouts of Gramineae are potent aneugens in human-derived liver cells (HepG2). Cancer Letters, 246 (1), 290-299.

Cambier, V., Hance, T., \& De Hoffmann, E. (2000). Variation of DIMBOA and related compounds content in relation to the age and plant organ in maize. Phytochemistry, 53, 223-229.

Cambier, V., Hance, T. \& De Hoffmann, E. (2001). Effects of 1,4benzoxazin- 3-one derivatives from maize on survival and fecundity of Metopolophium dirhodum (Walker) on artificial diet. Journal of Chemical Ecology, 27, 359-370.

Cardinal, A. J., Lee, M., Guthrie, W. D., Bing, J., Austin, D. F., Veldboom, L. R. \& Senior, M. L. (2006). Mapping of factors for resistance to leaf-blade feeding by European corn borer (Ostrinia nubilalis) in maize. Maydica, 51, 93-102.

Che, X. F., Zheng, C. L., Akiyama, S. I., \& Tomoda, A. (2011). 2 Aminophenoxazine-3-one and 2-amino-4, 4. ALPHA.-dihydro-4. ALPHA., 7-dimethyl-3H-phenoxazine-3-one cause cellular apoptosis by reducing higher intracellular $\mathrm{pH}$ in cancer cells. Proceedings of the Japan Academy, Series B, 87(4), 199-213.

Corcuera, L. J., Woodward, M. D., Helgeson, J. P., Kelman, A., \& Upper, C. (1978). 2,4-Dihydroxy-7-methoxy-2 H-1,4-benzoxazin$3(4 \mathrm{H})$-one, an inhibitor from Zea mays with differential activity against soft rotting Erwinia species. Plant Physiology, 61, 791-795.

Dakora, F. D., \& Phillips, D. A. (2002). Root exudates as mediators of mineral acquisition in low-nutrient environments. Plant and Soil 245(1), 35-47.

Davis, C. S., Ni, X., Quisenberry, S. S., \& Foster, J. E. (2000). Identification and quantification of hydroxamic acids in maize seedling root tissue and impact on western corn rootworm (Coleoptera: Chrysomelidae) larval development. Journal of Economic Entomology, 93(3), 989-992.

Dihm, K., Lind, M. V., Sunden, H., Ross, A., \& Svolainen, O. (2017). Quantification of benzoxazinoids and their metabolites in Nordic breads. Food Chemistry, 235, 7-13.

Ding, X., Yang, M., Huang, H., Chuan, Y., He, X., Li, C., Zhu, Y., \& Zhu, S. (2015). Priming maize resistance by its neighbors: activating 1, 4-benzoxazine-3-ones synthesis and defense gene expression to alleviate leaf disease. Frontiers in Plant Science, 6,830.

Elek, H., Smart, L., Martin, J., Ahmad, S., Gordon-Weeks, R., Anda, A., Welham, S., Werner, P., \& Pickett, J. (2013). Hydroxamic acids in Aegilops species and effects on Rhopalosiphum padi behaviour and fecundity. Bulletin of Insectology, 66(2), 213-220.

Erb, M., Flors, V., Karlen, D., De Lange, E., Planchamp, C., D’Alessandro, M., Turlings, T. C. \& Ton, J. (2009). Signal signature of aboveground-induced resistance upon belowground herbivory in maize. The Plant Journal, 59(2), 292-302.

Etzerodt, T., Maeda, K., Nakajima, Y., Laursen, B., Fomsgaard, I. S., \& Kimura, M. (2015). 2, 4-Dihydroxy-7-methoxy-2H-1, 4benzoxazin-3 (4H)-one (DIMBOA) inhibits trichothecene production by Fusarium graminearum through suppression of Tri6 expression. International Journal of Food Microbiology, 214, 123-128.
Friebe, A., Vilich, V., Hennig, L., Kluge, M., \& Sicker, D. (1998). Detoxification of Benzoxazolinone Allelochemicals from Wheat by Gaeumannomyces graminis var. tritici, G. graminis var. graminis, G. graminis var. avenae, and Fusarium culmorum. Applied and Environmental Microbiology, 64(7), 2386-2391.

Frost, C. J., Mescher, M. C., Carlson, J. E., \& De Moraes, C. M. (2008). Plant defense priming against herbivores: getting ready for a different battle. Plant Physiology, 146(3), 818-824.

Fuentes-Contreras, E., \& Niemeyer, H. M. (1998). DIMBOA glucoside, a wheat chemical defense, affects host acceptance and suitability of Sitobion avenae to the cereal aphid parasitoid Aphidius rhopalosiphi. Journal of Chemical Ecology, 24(2), 371-381.

Glauser, G., Marti, G., Villard, N., Doyen, G.A., Wolfender, J. L., Turlings, T. C., \& Erb, M. (2011). Induction and detoxification of maize 1,4-benzoxazin-3-ones by insect herbivores. The Plant Journal, 68, 901-911.

Glenn, A. E., Gold, S. E., \& Bacon, C. W. (2002). Fdb1 and Fdb2, Fusarium verticillioides loci necessary for detoxification of preformed antimicrobials from corn. Molecular Plant-Microbe Interactions, 15(2), 91 101.

Grün, S., Frey, M., \& Gierl, A. (2005). Evolution of the indole alkaloid biosynthesis in the genus Hordeum: distribution of gramine and DIBOA and isolation of the benzoxazinoid biosynthesis genes from Hordeum lecbleri. Phytochemistry, 66(11), 1264-1272.

Gordon-Weeks, R., Smart, L., Ahmad, S., Zhang, Y., Elek, H., Jing, H., Martin, J., \& Pickett, J. (2010). The role of the benzoxazinone pathway in aphid resistance in wheat. HGCA Project Report, 473, 1-66.

Hanhineva, K., Rogachev, I., Aura, A. M., Aharoni, A., Poutanen, K., \& Mykkanen, H. A. (2011). Qualitative characterization of benzoxazinoid derivatives in whole grain rye and wheat by LCMS metabolite profiling. Journal of Agricultural and Food Chemistry, 59(3), 921-927.

Huang, Z., Haig, T., Wu, H., An, M. \& Pratley, J. (2003). Correlation between phytotoxicity on annual ryegrass (Lolium rigidum) and production dynamics of allelochemicals within root exudates of an allelopathic wheat. Journal of Chemical Ecology, 29, 2263-2279.

Idinger, J., Coja, T., \& Blümel, S. (2006). Effects of the benzoxazoid DIMBOA, selected degradation products, and structure-related pesticides on soil organisms. Ecotoxicology and Environmental Safety, 65(1), 1-13.

Jampatong, C., McMullen, M. D., Barry, B. D., Darrah, L. L., Byrne, P. F., \& Kross, H. (2002). Quantitative trait loci for first- and second-generation European corn borer resistance derived from the maize inbred Mo47. Crop Science, 42, 584-593.

Jensen, B. M., Adhikari, K. B., Schnoor, H. J., Juel-Berg, N., Fomsgaard, I. S., \& Poulsen, L. K. (2017). Quantitative analysis of absorption, metabolism, and excretion of benzoxazinoids in humans after the consumption of high- and low-benzoxazinoid diets with similar contents of cereal dietary fbres: a crossover study. European Journal of Nutrition, 56(1), 387-397.

Kato, S., Shirato, K., Imaizumi, K., Toyota, H., Mizuguchi, J., Odawara, M., Che, X. F., Akivama, S., Abe, A. \& Tomoda, A. (2006). Anticancer effects of phenoxazine derivatives combined with tumor necrosis factor-related apoptosis-inducing ligand on pancreatic cancer cell lines, KLM-1 and MIA-PaCa-2. Oncology Reports, 15(4), 843-848.

Kia, S. H., Schulz, M., Ayah, E., Schouten, A., Müllenborn, C., Paetz, C., Schneider, B., Hofmann, D., Disko, U., Tabaglio, V. \& Marocco, A. (2014). Abutilon theophrasti's Defense Against the Allelochemical Benzoxazolin-2 (3H)-One: Support by Actinomucor elegans. Journal of Chemical Ecology, 40(11-12), 12861298.

Klenke, J. R., Russell, W. A., Guthrie, W. D., Martinson, C. A., \& Pedersen, W. L. (1987). Disease resistance in five cycles of" BS 9" corn synthetic selected for resistance to two generations of European corn borer. Phytopathology, 77(5), 735-739.

Krakowsky, M. D., Lee, M., Woodman-Clikeman, W. L., Long, M. J., \& Sharopova, N. (2004). QTL mapping of resistance to stalk tunneling by the European corn borer in RILs of maize population B73 $\times$ De811. Crop Science, 44, 274-282.

Kupferschmied, P., Maurhofer, M., \& Keel, C. (2013). Promise for plant pest control: root-associated pseudomonads with insecticidal activities. Frontiers in Plant Science, 4, 287. 
Lange, E. S., Balmer, D., Mauch-Mani, B., \& Turlings, T. C. (2014). Insect and pathogen attack and resistance in maize and its wild ancestors, the teosintes. New Phytologist, 204(2), 329-341.

Leszczynski, B., Matok, H., \& Dixon, A. F. G. (1992). Resistance of cereals to aphids: The interaction between hydroxamic acids and UDP-glucose transferases in the aphid Sitobion avenae (Homoptera: Aphididae). Journal of Chemical Ecology, 18(7), 1189-1200.

Maag, D., Dalvit, C., Thevenet, D., Köhler, A., Wouters, F. C., Vassão, D. G., Gershenzon, J., Wolfender, J. L., Turlings, T. C., Erb, M. \& Glauser, G. (2014). 3- $\beta$-D-Glucopyranosyl-6-methoxy2-benzoxazolinone (MBOA-N-Glc) is an insect detoxification product of maize 1, 4-benzoxazin-3-ones. Phytochemistry, 102, $97-$ 105.

Maag, D., Erb, M., Bernal, J. S., Wolfender, J. L., Turlings, T. C., \& Glauser, G. (2015). Maize domestication and anti-herbivore defences: leaf-specific dynamics during early ontogeny of maize and its wild ancestors. PloS ONE, 10(8), e0135722.

Macías, F. A., Chinchilla, N., Arroyo, E., Molinillo, J. M., Marin, D., \& Varela, R. M. (2010). Combined strategy for phytotoxicity enhancement of benzoxazinones. Journal of Agricultural and Food Chemistry, 58(3), 2047-2053.

Marcacci, S., Raveton, M., Ravanel, P., \& Schwitzguébel, J. P. (2005). The possible role of hydroxylation in the detoxification of atrazine in mature vetiver (Chrysopogon zizanioides Nash) grown in hydroponics. Zeitschrift für Naturforschung C, 60(5-6), 427-434.

Maresh, J., Zhang, J., \& Lynn, D. G. (2006). The innate immunity of maize and the dynamic chemical strategies regulating twocomponent signal transduction in Agrobacterium tumefaciens. ACS Chemical Biology, 1(3), 165-175.

Meihls, L. N., Handrick, V., Glauser, G., Barbier, H., Kaur, H., Haribal, M. M., \& Jander, G. (2013). Natural variation in maize aphid resistance is associated with 2, 4-dihydroxy-7-methoxy-1, 4benzoxazin-3-one glucoside methyltransferase activity. The Plant Cell, 25(6), 2341-2355.

Meyer, S. L., Rice, C. P., \& Zasada, I. A. (2009). DIBOA: Fate in soil and effects on root-knot nematode egg numbers. Soil Biology and Biochemistry, 41(7), 1555-1560.

Miller, J. D., Fielder, D. A., Dowd, P. F., Norton, R. A., \& Collins, F. W. (1996). Isolation of 4-acetyl-benzoxazolin-2-one (4-ABOA) and diferuloylputrescine from an extract of gibberella ear rotresistant corn that blocks mycotoxin biosynthesis, and the insect toxicity of 4-ABOA and related compounds. Biochemical Systematics and Ecology, 24(7), 647-658.

Mukanganyama, S., Figueroa, C. C., Hasler, J. A., \& Niemeyer, H. M. (2003). Effects of DIMBOA on detoxification enzymes of the aphid Rhopalosiphum padi (Homoptera: aphididae). Journal of Insect Physiology, 49(3), 223-229.

Neal, A. L., Ahmad, S., Gordon-Weeks, R., \& Ton, J. (2012). Benzoxazinoids in root exudates of maize attract Pseudomonas putida to the rhizosphere. PLoS ONE, 7(4), e35498.

Neal, A., \& Ton, J. (2013). Systemic defense priming by Pseudomonas putida KT2440 in maize depends on benzoxazinoid exudation from the roots. Plant Signaling \& Behavior, 8(1), e22655.

Nicol, D., Copaja, S. V., Wratten, S. D., \& Niemeyer, H. M. (1992). A screen of worldwide wheat cultivars for hydroxamic acid levels and aphid antixenosis. Annals of Applied Biology, 121(1), 11-18.

Nicol, D., Wratten, S. D., Eaton, N., \& Copaja, S. V. (1993). Effects of DIMBOA levels in wheat on the susceptibility of the grain aphid (Sitobion avenue) to deltamethrin. Annals of Applied Biology, 122(3), 427-433.

Niemeyer, H. M. (1988a). Hydroxamic acids (4-hydroxy-1,4benzoxazin-3-ones), defense chemicals in the Gramineae. Phytochemistry, 27, 3349-3358.

Niemeyer, H. M. (1988b). Hydroxamic acid content of Triticum species. Euphytica, 37(3), 289-293.

Niemeyer, H. M. (2009). Hydroxamic acids derived from 2-hydroxy$2 \mathrm{H}-1$,4-benzoxazin-3(4H)-one: key defense chemicals of cereals. Journal of Agricultural and Food Chemistry, 57, 1677-1696.

Nomura, T., Ishihara, A., Imaishi, H., Ohkawa, H., Endo, T. R., \& Iwamura, H. (2003). Rearrangement of the genes for the biosynthesis of benzoxazinones in the evolution of Triticeae species. Planta, 217(5), 776-782.
Nomura, T., Ishihara, A., Iwamura, H., \& Endo, T. R. (2007). Molecular characterization of benzoxazinone-deficient mutation in diploid wheat.Phytochemistry, 68(7), 1008-1016.

Park, W. J., Schäfer, A., Prinsen, E., Van Onckelen, H., Kang, B. G., \& Hertel, R. (2001). Auxin-induced elongation of short maize coleoptile segments is supported by 2, 4-dihydroxy-7-methoxy-1, 4-benzoxazin-3-one. Planta, 213(1), 92-100.

Pedersen, H. A., Laursen, B., Mortensen, A., \& Fomsgaard I. S. (2011). Bread from common cereal cultivars contains an important array of neglected bioactive benzoxazinoids. Food Chemistry, 127, 1814-1820.

Perez, F. J. (1990). Allelopathic effect of hydroxamic acids from cereals on Avena sativa and A. fatua. Phytochemistry, 29, 773-776.

Petho, M. (1993). Occurrence of cyclic hydroxamic acids in the tissues of barnyard grass (Echinochloa crus-galli), and their possible role in allelopathy). Acta Agronomica Hungarica, 42, 197-202.

Pihlava, J., Hellstrom, J., Kurtelius, T., \& Mattila, P. (2018). Flavonoids, anthocyanins, phenolamides, benzoxazinoids, lignans and alkylresorcinols in rye (Secale cereale) and some rye products. Journal of Cereal Science, 79, 183-192.

Poschenrieder, C., Tolrà, R. P., \& Barceló, J. (2005). A role for cyclic hydroxamates in aluminium resistance in maize? Journal of Inorganic Biochemistry, 99(9), 1830-1836.

Poupaert, J., Carato, P., \& Colacino, E. (2005). 2 (3H)-benzoxazolone and bioisosters as "privileged scaffold" in the design of pharmacological probes. Current Medicinal Chemistry, 12(7), $877-$ 885.

Prinz, S., Schauberger, D., Bauer, I. M., Knasmueller, S., \& Kopp, B. (2010). Aneugenic 2, 4-dihydroxy-7-methoxy-1, 4-benzoxazin-3one (DIMBOA) and 2, 4-dihydroxy-1, 4-benzoxazin-3-one (DIBOA) in sprouts of Triticum aestivum cultivars - A 'safety health food'? Food Chemistry, 121(4), 973-979.

Robert, C. A., Veyrat, N., Glauser, G., Marti, G., Doyen, G. R., Villard, N., Gaillard, M. D., Köllner, T. G., Giron, D., Body, M. \& Babst, B. A. (2012). A specialist root herbivore exploits defensive metabolites to locate nutritious tissues. Ecology Letters, 15(1), 55-64.

Rosenfeld, M. J., \& Forsberg, S. R. (2009). U.S. Patent No. 7,521,468. Washington, DC: U.S. Patent and Trademark Office.

Rostás, M. (2007). The effects of 2,4-dihydroxy-7-methoxy-1,4benzoxazin-3-one on two species of Spodoptera and the growth of Setosphaeria turcica in vitro. Journal of Pest Science, 80, 35-41.

Santiago, R., Cao, A., Butrón, A., López-Malvar, A., Rodríguez, V. M. Sandoya, G. V., \& Malvar, R. A. (2017). Defensive changes in maize leaves induced by feeding of Mediterranean corn borer larvae. BMC Plant Biology, 17:44.

Sasai, H., Ishida, M., Murakami, K., Tadokoro, N., Ishihara, A., Nishida, R., \& Mori, N. (2009). Species-specific glucosylation of DIMBOA in larvae of the rice armyworm. Bioscience, Biotechnology, and Biochemistry, 73(6), 1333-1338.

Saunders, M., \& Kohn, L. M. (2008). Host-synthesized secondary compounds influence the in vitro interactions between fungal endophytes of maize. Applied and Environmental Microbiology, 74(1), 136-142.

Søltoft, M., Jorgensen, L. N., Svensmark, B., \& Fomsgaard, I. S. (2008). Benzoxazinoid concentrations show correlation with Fusarium Head Blight resistance in Danish wheat varieties. Biochemical Systematics and Ecology, 36, 245-259.

Song, Y. Y., Cao, M., Xie, L. J., Liang, X. T., Zeng, R. S., Su, Y. J., Huang, J. H., Wang, R. L. \& Luo, S. M. (2011). Induction of DIMBOA accumulation and systemic defense responses as a mechanism of enhanced resistance of mycorrhizal corn (Zea mays L.) to sheath blight. Mycorrbiza, 21(8), 721-731.

Steffensen, S. K., Adhikari, K. B., Laursen, B. B., Jensen, C., Gregersen, P. L., Bhattarai, B., Maraís, L. M., Schnorr, H., Jensen, B. M., Poulsen, L. K. \& Nielsen, C. H. (2017). Bioactive small molecules in commercially available cereal food: Benzoxazinoids. Journal of Food Composition and Analysis, 64, 213-222.

Szczepaniec, A., Widney, S. E., Bernal, J. S., \& Eubanks, M. D. (2013). Higher expression of induced defenses in teosintes (Zea spp.) is correlated with greater resistance to fall armyworm, Spodoptera frugiperda. Entomologia Experimentalis et Applicata, 146(2), 242-251. 
Tabaglio, V., Gavazzi, C., Schulz, M., \& Marocco, A. (2008). Alternative weed control using the allelopathic effect of natural benzoxazinoids from rye mulch. Agronomy for Sustainable Development, 28(3), 397-401.

Takahashi, C. G., Kalns, L. L., \& Bernal, J. S. (2012). Plant defense against fall armyworm in micro-sympatric maize (Zea mays ssp. mays) and Balsas teosinte (Zea mays ssp. parviglumis). Entomologia Experimentalis et Applicata, 145(3), 191-200.

Tzin, V., Hojo, Y., Strickler, S. R., Bartsch, L. J., Archer, C. M., Ahern, K. R., Zhou, S., Christensen, S. A., Galis, I., Mueller, L. A. \& Jander, G. (2017). Rapid defense responses in maize leaves induced by Spodoptera exigua caterpillar feeding. Journal of Experimental Botany, 68(16), 4709-4723.

Wang, J. W., Xu, T., Zhang, L. W., Zhong, Z. M., \& Luo, S. M. (2007). Effects of methyl jasmonate on hydroxamic acid and phenolic acid content in maize and its allelopathic activity to Echinochloa crusgalli (L.). Allelopatby Journal, 19, 161-169.

Wenger, K., Bigler, L., Suter, M. F., Schönenberger, R., Gupta, S. K., $\&$ Schulin, R. (2005). Effect of corn root exudates on the degradation of atrazine and its chlorinated metabolites in soils. Journal of Environmental Quality, 34(6), 2187-2196.

Wu, H., Haig, T., Pratley, J., Lemerle, D., \& An, M. (2001). Allelochemicals in wheat (Triticum aestivum L.): cultivar difference in the exudation of phenolic acids. Journal of Agricultural and Food Chemistry, 49(8), 3742-3745.

Wu, W. H., Chen, T. Y., Lu, R. W., Chen, S. T., \& Chang, C. C. (2012). Benzoxazinoids from Scoparia dulcis (sweet broomweed) with antiproliferative activity against the DU-145 human prostate cancer cell line. Phytochemistry, 83, 110-115.
Xia, L., He, K. L., Wang, Z. Y., \& Bai, S. X. (2010). Quantitative trait loci for Asian corn borer resistance in maize population Mc37 $\mathrm{x}$ Zi330. Agricultural Sciences in China, 9, 77-84.

Yang, M., Zhang, Y., Qi, L., Mei, X., Liao, J., Ding, X., Deng, W., Fan, L., He, X., Vivanco, J. M. \& Li, C. (2014). Plant-plantmicrobe mechanisms involved in soil-borne disease suppression on a maize and pepper intercropping system. PloS ONE, 9(12), p.e115052.

Yin, J., Chen, J., Cao, Y., Li, K., Hu, Y., \& Sun, J. (2005). Wheat resistance induced by exogenous chemicals to the wheat aphid, Sitobion avenae (F.) and the oriental armyworm, Mythimna separata (Walker). Acta Entomologica Sinica, 48(5), 718-724.

Zasada, I. A., Meyer, S. L. F., Halbrendt, J. M., \& Rice, C. (2005). Activity of hydroxamic acids from Secale cereale against the plantparasitic nematodes Meloidogyne incognita and Xiphinema americanum. Phytopathology, 95(10), 1116-1121.

Zheng, C. L., Che, X. F., Akiyama, S. I., Miyazawa, K., \& Tomoda, A. (2010). 2-Aminophenoxazine-3-one induces cellular apoptosis by causing rapid intracellular acidification and generating reactive oxygen species in human lung adenocarcinoma cells. International Journal of Oncology, 36(3), 641-650.

Zheng, L., McMullen, M. D., Bauer, E., Schön, C. C., Gierl, A., \& Frey, M. (2015). Prolonged expression of the BX1 signature enzyme is associated with a recombination hotspot in the benzoxazinoid gene cluster in Zea mays. Journal of Experimental Botany, 66(13), 3917-3930.

Zheng, Y., Zhao, Y., Liu, X., Yao, J., \& Dong, F. (2008). Chemical inducement of 2, 4-dihydroxy-7-methoxy-1, 4-benzoxazin-3-one (DIMBOA) in wheat seedlings. Allelopathy Journal, 21(2), 263-271.

\section{Benzoksazinoidi - zaštitni sekundarni metaboliti žitarica: Uloga i primena}

\section{Sanja Mikić · Shakoor Ahmad}

Sažetak: Benzoksazinoidi su sekundarni metaboliti biljaka koji obezbeđuju zaštitu od brojnih štetočina i patogena. Utvrđeni su kod monokotila, poput trava, i nekoliko porodica dikotila. Među usevima, benzoksazinoidi su najbolje opisani kod pšenice, kukuruza i raži. Ovi prirodni pesticidi imaju inhibitorno dejstvo na korove, insekte, fitopatogene gljive, bakterije i nematode. Pored toga, benzoksazinoidi pokazuju sposobnost da potisnu stvaranje mikotoksina, ublaže negativno dejstvo nedostatka mikroelemenata i toksičnosti i privuku korisne bakterije u rizosferi useva. U ovom radu, sažete su prednosti i mogućnosti primene ovih alelojedinjenja u zaštiti žitarica, ukazujući na njihov značaj u proizvodnji sa integralnim merama zaštite u kojoj je smanjena upotreba pesticida, ili u organskoj proizvodnji u kojoj se pesticidi ne koriste. S tim u vezi, razmatraju se moguća ograničenja i rizici primene benzoksazinoida. Konačno, ukazuje se na dostupnu germplazmu sa velikim sadržajem benzoksazinoida koja može poslužiti kao izvor otpornosti u oplemenjivačkim programima žitarica. Ključne reči: alelojedinjenja, benzoksazinoidi, DIMBOA, oplemenjivanje žitarica, sekundarni metaboliti, zaštita od štetočina, zaštitne mere 